\title{
Significance of Tissue Expression and Serum Levels of Angiopoietin-like Protein 4 in Breast Cancer Progression: Link to NF-xB /P65 Activity and Pro-Inflammatory Cytokines
}

\author{
Noha M Shafik ${ }^{1 *}$, Dareen A Mohamed², Asmaa E Bedder², Ahmed M El-Gendy3 ${ }^{3}$
}

\begin{abstract}
Background: The molecular mechanisms linking breast cancer progression and inflammation still remain obscure. The aim of the present study was to investigate the possible association of angiopoeitin like protein 4 (ANGPTL4) and its regulatory factor, hypoxia inducible factor-1 $\alpha$ (HIF-1 $\alpha)$, with the inflammatory markers

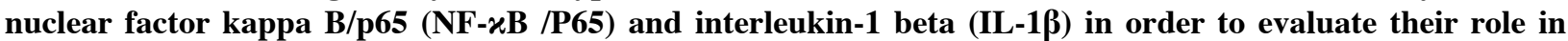
inflammation associated breast cancer progression. Materials and Methods: Angiopoietin-like protein 4 (ANGPTL4) mRNA expressions were evaluated using quantitative real time PCR and its protein expression by immunohistochemistry. DNA binding activity of NF- $x$ B /P65 was evaluated by transcription factor binding immunoassay. Serum levels of ANGPTL4, HIF-1 $\alpha$ and IL-1 $\beta$ were immunoassayed. Tumor clinico-pathological features were investigated. Results: ANGPTL4 mRNA expressions and serum levels were significantly higher in high grade breast carcinoma $(1.47 \pm 0.31$ and $184.98 \pm 18.18$, respectively) compared to low grade carcinoma $(1.21 \pm 0.32$ and $171.76 \pm 7.58$, respectively) and controls $(0.70 \pm 0.02$ and $65.34 \pm 6.41$, respectively $),(p<0.05)$. Also, ANGPTL4 high/moderate protein expression was positively correlated with tumor clinico-pathological features. In addition, serum levels of HIF-1 $\alpha$ and IL-1 $\beta$ as well as NF- $x$ B /P65 DNA binding activity were significantly higher in high grade breast carcinoma $(148.54 \pm 14.20,0.79 \pm 0.03$ and $247.13 \pm 44.35$ respectively $)$ than their values in low grade carcinoma $(139.14 \pm 5.83,0.34 \pm 0.02$ and $184.23 \pm 37.75$, respectively) and controls $(33.95 \pm 3.11,0.11 \pm 0.02$ and $7.83 \pm 0.92$, respectively $),(p<0.001)$. Conclusion: ANGPTL4 high serum levels and tissue expressions in advanced grade breast cancer, in addition to its positive correlation with tumor clinico-pathological features and HIF-1 $\alpha$ could highlight its role as one of the signaling factors involved in breast cancer progression. Moreover, novel correlations were found between ANGPTL4 and the inflammatory markers, IL-1 $\beta$ and NF- $x$ B/p65, in breast cancer, which may emphasize the utility of these markers as potential tools for understanding interactions for axes of carcinogenesis and inflammation contributed for cancer progression. It is thus hoped that the findings reported here would assist in the development of new breast cancer management strategies that would promote patients' quality of life and ultimately improve clinical outcomes. However, large-scale studies are needed to verify these results.
\end{abstract}

Keywords: Breast cancer - angiopoietin -like protein -4 (ANGPTL4) - hypoxia inducible factor-1 alpha

Asian Pac J Cancer Prev, 16 (18), 8579-8587

\section{Introduction}

Breast carcinoma is the most common cancer in females and is the principal cause of death among women globally (Taghavi et al., 2012). Hypoxia and inflammation associated cancer are important risk factors contributing to the breast cancer pathogenesis (Philip et al., 2004). Angiopoietin-like protein 4 (ANGPTL4) is a member of the angiopoietin family of proteins that have a similar structure. The native full-length ANGPTL4 exists in the form of dimeric or tetrameric complexes that can undergo proteolytic processing to generate the $\mathrm{N}$-terminal coiledcoil fragment (nANGPTL4) and the $\mathrm{COOH}$-terminal fibrinogen-like domain (cANGPTL4) (Feingold et al.,
2012). It is highly expressed in adipose tissue, liver, placental tissue, and ischemic tissues (Santulli, 2014). The roles of ANGPTL4 in human cancers remain controversial. However, a novel role of ANGPTL4 in redox-mediated cancer progression has been postulated, hypothesized to be exhibited through its $\mathrm{COOH}$-terminal fibrinogen-like domain (Feingold et al., 2012). Several lines of evidence have indicated that ANGPTL4 can be stimulated by inflammatory and hypoxic conditions (Santulli, 2014). Hypoxia observed in tumors has been noted to be the main cause of cell cycle arrest, apoptosis and angiogenesis (Xia et al., 2014). Cellular oxygensignaling pathway requires the participation of hypoxiainducible factors (HIFs), which exist in two types, 
oxygen-sensitive alpha subunit (HIF- $\alpha$ ) and a constitutive beta subunit (HIF- $\beta$ ). Both subunits are heterodimeric, facilitating both oxygen delivery and adaptation to oxygen deprivation (Gaballah et al., 2014). HIF-1 $\alpha$ is a transcription factor that binds to hypoxia responsive element (HRE), which in turn enhances the transcription of hypoxia-responsive genes. Thus, the survival of tumor cells is increased under hypoxic conditions (Zhang et al., 2013). A growing body of evidences highlights the role of HIF- $1 \alpha$ as a regulator of ANGPTL4 (Khong et al., 2013). NF-kB is a sequence-specific transcription factor that plays a crucial role in linking inflammation and innate immunity to breast oncogenesis (Laere et al., 2006). However, cytoplasmic NF- $x \mathrm{~B}$ is deactivated by binding of the inhibitory proteins IKB- $\alpha$, IKB- $\beta$, IKB- $\varepsilon$, $\mathrm{p} 105$, and $\mathrm{p} 100$. NF- $\varkappa \mathrm{B}$ activity occurs by its translocation to the nucleus, binding to $x \mathrm{~B}$ sites, and regulating target genes as a result of the phosphorylation and subsequent degradation of the inhibitory subunits (González-Ramos et al., 2012). Its constitutive activation is one of the early key events involved in breast cancer progression. Indeed, extant studies indicate that NF- $x \mathrm{~B}$ signaling stimulates proliferation and prevents apoptosis (Biswas et al., 2003). The p65 subunit of NF- $x \mathrm{~B}(\mathrm{NF}-x \mathrm{~B} / \mathrm{p} 65)$ is responsible for most of NF- $x \mathrm{~B}$ 's transcriptional activity (van Loo and Beyaert, 2011). A cross-talk has been established between the NF- $x$ B and the HIF pathways, as HIF-1 redox-sensitive induction might be due to binding at a distinct element in NF- $x \mathrm{~B}$ proximal promoter. Moreover, activation of $\mathrm{NF}-\varkappa \mathrm{B}$ pathway may be the main contributor of HIF-1 induction (Görlach and Bonello, 2008; Wang et al., 2015). The expression of important molecules in tumorigenesis such as chemokines, and inflammatory cytokines, all of which promote tumor cell invasion and angiogenesis - is regulated by NF- $x \mathrm{~B}$ (Biswas et al., 2003). IL-1 $\beta$ is a member of IL-1 family that plays a central role in immune and inflammatory response regulation (Rider et al., 2011). IL- $1 \beta$ was found to be the primary mediator in context of cancer-associated chronic inflammation (Katanov et al., 2015). Interestingly, in cancer cells, HIF- $1 \alpha$ was found to be activated by the proinflammatory cytokine IL- $1 \beta$ in a NF- $x$ B dependent manner (Tewari et al., 2012). Thus it is necessary to focus research efforts on critical molecular phenomena that may link carcinogenesis and hypoxia to inflammation in tumor microenvironment. The ultimate goal of such studies is to propose new treatment strategies that could improve survival rates and patients' quality of life. Thus, The aim of present study was to investigate the possible association of angiopoeitin like protein 4 (ANGPTL4) and its regulatory factor, hypoxia inducible factor-1 $\alpha$ (HIF-1 $\alpha$ ) with nuclear factor kappa B/p65 $(\mathrm{NF}-x \mathrm{~B} / \mathrm{P} 65)$ and interleukin-1 beta (IL-1 $\beta$ ) in order to evaluate their role in inflammation associated breast cancer progression.

\section{Materials and Methods}

Informed written consent was obtained from all patients prior to commencing the study. The study protocol was approved by the Local Research Ethics Committee, Tanta University and was in accordance with the principles of the
Declaration of Helsinki II. This study included 74 women aged 40-56 years, who were admitted to the surgical department of Tanta University Hospitals for breast surgeries. All participants underwent clinical examination and routine laboratory investigations prior to being divided into two groups. Group I $(n=20)$ comprised of women who underwent surgical removal of benign breast lesions. As a part of this procedure, normal breast tissue samples were taken in the vicinity of the lesions, and served as controls. Group II $(n=54)$ consisted of female patients that had primary invasive breast carcinoma (confirmed by fine-needle aspiration) with no other primary cancers, all of whom underwent modified radical mastectomy or quadrantectomy with axillary clearance. Breast cancer biopsies were taken from the apparent lesion, processed by standard oncological procedures, studied and graded by a specialized pathologist. According to the histopathological grading, Group II was further subdivided into Group IIa consisting of 10 patients with low-grade cancer (Grade I) and Group IIb consisting of 44 patients with highgrade cancer (Grade II \& III). None of the patients with invasive breast carcinoma had received any neoadjuvant therapy. Patients with other malignancies, any endocrinal disturbances, or systemic infections, those that received neoadjuvant therapy and smokers were excluded from the study. During the surgical procedures, tissue samples were obtained and processed by standard oncological procedures. These were subsequently divided into two portions, whereby one portion was kept in liquid nitrogen for ANGPTL4 mRNA gene expression investigations, while the other was kept in $10 \%$ formalin solution for histopathological and immunohistochemistry studies.

\section{Biochemical and immunoassays:}

All study participants followed overnight fasting protocol prior to the morning surgery. Immediately before the induction of general anesthesia, their early morning venous blood samples (10 $\mathrm{ml}$ in plain vacutainer tubes) were taken and transferred slowly into a dry sterile centrifuge tube. The samples were allowed to clot at room temperature, before being centrifuged at $2000 \mathrm{rpm}$ for 10 minutes. Finally, serum was separated and stored at $-70^{\circ} \mathrm{C}$ for different estimations.

Enzyme-linked immunosorbent assays (ELISA) were used to detect the levels of serum ANGPTL4 (Cat \# DY3485, R\&D Systems, ANGPTL4 Duo kit, Minneapolis, USA), the levels of serum HIF-1 $\alpha$ (R\&D Systems, Minneapolis, MN 55413, USA) and serum levels of IL-1 $\beta$ (Cat \# SEA563Hu, Cloud Clone Corp, USA). All ELISA assays were performed according to the manufacturer's instructions.

Preparation of peripheral blood mononuclear cells (PBMCs):

PMNCs were prepared using Ficoll-Hypaque (Pharmacia, Uppsala, Sweden) by means of density gradient centrifugation. First, $5 \mathrm{ml}$ of Heparinised blood was layered on Ficoll and, after centrifugation for 30 minutes at $500 \mathrm{xg}$ at room temperature, PBMC were harvested from the white interphase before being washed with phosphate buffered saline. The PBMCs samples 
were stored at $-80^{\circ} \mathrm{C}$ until required for analysis of $\mathrm{NF} x \mathrm{~B}$ DNA-binding activity.

NF $x$ B activation was examined by using transcription factor binding assay kit as described below:

\section{1-Nuclear proteins isolation}

Nuclear Extract kit (Cat \# 40010, Active Motif, Carlsbad, CA, USA) was used to isolate nuclear proteins from PBMCs extract according to the manufacturer's instructions. Briefly, the kit provided ice-cold hypotonic buffer containing $10 \mathrm{~mL} \mathrm{KCL}, 10 \mathrm{mmol} / \mathrm{L}$ HEPES (pH 7.9), $0.1 \mathrm{mmol} / \mathrm{L}$ EDTA, $0.1 \mathrm{mmol} / \mathrm{L}$ ethylene glycol tetraacetic acid, $1 \mathrm{mmol} / \mathrm{L}$ DTT; and Protease inhibitors. $0.8 \mathrm{~mL}$ of this ice-cold buffer was used for the samples. Incubation of homogenates on ice for $20 \mathrm{~min}$, followed by adding $50 \mu \mathrm{L}$ of $10 \%$ Nonidet P-40, then vortexed for $30 \mathrm{~s}$ and centrifuged for $2 \mathrm{~min}$ at $4{ }^{\circ} \mathrm{C}$ in an Eppendorf centrifuge. After supernatants were decanted, the nuclear pellets were suspended in an ice-cold hypertonic buffer. Then, a single wash with hypotonic buffer without Nonidet P-40 was performed. Next, they were incubated on ice for $20 \mathrm{~min}$ at $4{ }^{\circ} \mathrm{C}$, mixed and centrifuged for 12 min at $4{ }^{\circ} \mathrm{C}$. The supernatants were collected as nuclear extracts and stored at $-80{ }^{\circ} \mathrm{C}$ until required (Gong et al., 2002). Concentrations of total proteins in the samples were determined according to the method described by Bradford (Bradford, 1976).

\section{2-Determination of DNA-binding activity of $N F-k B / p 65$}

The ELISA-based TransAM ${ }^{\mathrm{TM}}$ NFxB p65 protein assay was used to evaluate $\mathrm{NF} \varkappa \mathrm{B} / \mathrm{p} 65$ DNA-binding activity (Cat \# 40096, Active Motif, Carlsbad, CA, USA), according to the manufacturer's instructions. Briefly, the kit provided a duplexed NF- $x$ B oligonucleotide containing a $x \mathrm{~B}$ consensus sequence, which was attached to the surface of 96-well plates. Incubation with antibodies against the activated forms of $\mathrm{NF} x \mathrm{~B} / \mathrm{p} 65$ was performed, allowing the NF- $x \mathrm{~B}$ activated dimers in $20 \mu \mathrm{g}$ nuclear extract bound to the attached oligonucleotide to be specifically and quantitatively detected. Then, incubation was performed with an enzyme-linked (horseradish peroxidase) secondary antibody, used for colorimetric scoring (Van Laere et al., 2006). The absorbance was measured on an ELISA reader at $450 \mathrm{~nm}$ with a reference wavelength of $655 \mathrm{~nm}$.

Estimation of ANGPTL4 mRNA expression levels by real-time $P C R$

RNA extraction, cDNA synthesis and Real-time quantitative PCR: Total RNA was extracted from breast tissue samples using RN easy Mini Kit (Roche Diagnostics, GmbH, Mannheim, Germany) according to manufacturer's instructions. RNA was eluted, its concentration was measured spectrophotometrically and RNA samples were subsequently stored at $-80^{\circ} \mathrm{C}$ until required. Each RNA sample was converted to cDNA using RT Superscript II (Cat \# K1632, Thermo Scientific Fermentas, St. Leon-Ro, Germany), dNTP, and random primers (Roche, Mannheim, Germany) according to the manufacturer's instructions. cDNA corresponding to the RNA was used as a template for real-time PCR. PCR reactions were performed using
Power SYBR Green PCR Master Mix and 7500 Fast Real-Time PCR System (Applied Biosystems, CA, USA). Sequence-specific primers were as follows: ANGPTL4: forward5'-ATTCTTTCCAGCGGCTTCTG-3', reverse: 5'-GAGGACTGGAGACGCGGAG-3' (According to gene bank accession No: NM_001039667), $\beta$-actin: forward: 5'- TGGCATTG CCGACAGGATGCAGAA-3', reverse: 5'-CTCGTCA TACTCCTGCTTGCTGAT-3' (According to gene bank accession No: NM_001101.3). $\beta$-actin primers were used as an internal control. RealTime PCR was performed according to the manufacturer's instructions and comprised of denaturation at $95^{\circ} \mathrm{C}$ for 10 $\mathrm{s}$, followed by 40 cycles of $95^{\circ} \mathrm{C}$ for $5 \mathrm{~s}$ and $60{ }^{\circ} \mathrm{C}$ for $20 \mathrm{~s}$. Presence of the expected amplification fragments without unanticipated products and primers was confirmed by melting curve analysis. Comparative $\mathrm{Ct}$ (threshold cycle) method was used to determine relative product amounts, according to the Applied Biosystems instructions. All expression data were normalized by dividing the target amount by the amount of $\beta$-actin for each sample.

\section{Histochemical and immunohistochemistry studies:}

For histopathological study, breast tissue biopsies were embedded in paraffin. For this purpose $5 \mu \mathrm{m}$ slices were stained with hematoxylin \& eosin ( $\mathrm{H} \& \mathrm{E})$. For immunohistochemical staining, $4 \mathrm{~mm}$ thick sections were formed. The tissue sections were deparaffinized and rehydrated. Slides were incubated in $3 \% \mathrm{H} 2 \mathrm{O} 2$ for 10 minutes to reduce nonspecific background staining arising due to endogenous peroxides. For antigen retrieval, specimens were heated for $20 \mathrm{~min}$ in $10 \mathrm{mmol} / \mathrm{l}$ citrate buffer $(\mathrm{pH} 6.0)$ in a microwave oven $(700 \mathrm{~W})$. Following incubation with Ultra V Block (Lab Vision Corporation, Fremont, California, USA) for $7 \mathrm{~min}$ at room temperature to block background staining, slides were incubated with ER (rabbit polyclonal, ab37438), PR (rabbit monoclonal, ab16661), HER-2 (rabbit monoclonal, ab134182), KI67 (mouse monoclonal, ab15580), CK5/6 (mouse monoclonal, ab86974), EGFR (rabbit monoclonal, $\mathrm{ab} 2430)$ and Mouse monoclonal to angiopoietin-like 4 (1:150 life science inc. Cat \# MAB019Ra21) overnight at room temperature in a humid chamber. Antibody binding was detected using the Ultra Vision LP Detection System (Lab Vision Corporation) according to the manufacturer's recommendations. Color development was performed with 3, 30-diaminobenzidine and counterstained with hematoxylin. Internal adipose breast tissue served as positive control for ANGPTL4, whereas negative controls were obtained by replacing the primary antibody with non-immune immunoglobulin G. Immunostaining results for ER, PR, HER2/new, EGFR and CK5/6 were used for molecular subdivision of breast cancers (Holliday and Speirs, 2011).

Immunostaining results pertaining to ANGPTL4 were evaluated by image analysis ( $\mathrm{Q}$ win Leica software). The percentage of positive cells was rated by assigning the 0 score to $0-5 \%, 1$ score to $6-25 \%$, a score of 2 to $26-50 \%$, and 3 to more than $50 \%$. Similarly, the staining intensity was rated by assigning 0 to no staining, 1 to weak staining, 2 to moderate staining, and 3 to strong staining. The percentage and intensity scores were added to an overall 
score, whereby the ANGPTL4 protein expression with an overall score of 0-2 was designated as 'low/negative and that with an overall score of 3-6 was designated as 'high/ moderate' (Yi et al., 2013).

\section{Statistical analysis:}

The data were analyzed using statistical package for the social science (SPSS) version 20.0 software (SPSS Inc., Chicago, IL, USA). Quantitative data expressed as mean and standard deviation. Categorical variables were compared using Chi-square test. Multiple comparisons were performed by one-way analysis of variance (ANOVA) followed by Tukey's post-hoc test. Correlations were analyzed using the Pearson test. Receiver operating characteristics (ROC) analysis was used to identify the optimal threshold values of the studied parameters.

\section{Results}

A statistical comparison using ANOVA test followed by Tukey's test was performed between the studied groups with respect to the age and laboratory biochemical findings, as demonstrated in Table 1. No statistically significant differences were detected between the studied groups regarding age $(p>.05)$. On the other hand, ANGPTL4 mRNA relative expression levels were significantly higher in Group IIb $(1.47 \pm 0.31)$ compared to Group IIa (1.21 \pm 0.32 ). Once again, both groups had higher values than those measured in the controls (Group I) $(0.7 \pm 0.02),(p<$ $.001)$. In addition, in high grade breast carcinoma patients
(Group IIb), the serum levels of ANGPTL4, HIF-1 $\alpha$, NF$x \beta / \mathrm{P} 65$ and IL-1 $\beta(184.98 \pm 18.18 \mathrm{ng} / \mathrm{ml}, 148.54 \pm 14.20$ $\mu \mathrm{g} / \mathrm{ml}, 0.79 \pm 0.03$ and $247.13 \pm 44.35 \mathrm{pg} / \mathrm{ml}$, respectively) were significantly higher than those in low-grade cancer group (IIa) $(171.76 \pm 7.58 \mathrm{ng} / \mathrm{ml}, 139.14 \pm 5.83 \mu \mathrm{g} / \mathrm{ml}$, $0.34 \pm 0.02$ and $184.23 \pm 37.75 \mathrm{pg} / \mathrm{ml}$, respectively) and both were higher than those measured in the control group $(65.34 \pm 6.41 \mathrm{ng} / \mathrm{ml}, 33.95 \pm 3.11 \mu \mathrm{g} / \mathrm{ml}, 0.11$ \pm 0.02 and $7.83 \pm 0.92 \mathrm{pg} / \mathrm{ml}$, respectively) $(p<.001)$. Table (2) presents the immunohistochemical findings of cancer and control groups, by using chi-square test, significant differences in ANGPTL4 protein expression were revealed between control and study groups. More specifically, high/moderate ANGPTL4 expression was found in $86.4 \%(38 / 44)$ of the high-grade breast cancer group (Group IIb), and 40\% (4/10) of low-grade breast cancer group (Group IIa), compared to only $25 \%$ (5/20) of the control cases. When the studied parameters in breast

\section{Table 2. Immunohistochemical Results of ANGPTL4} in Control and Cancer groups

\begin{tabular}{ccc}
\hline $\begin{array}{c}\text { Group I } \\
(\text { control }) \\
(\mathrm{n}=20)\end{array}$ & $\begin{array}{c}\text { Group IIa } \\
(\text { low grade cancer }) \\
(\mathrm{n}=10)\end{array}$ & $\begin{array}{c}\text { Group IIb } \\
\text { (high grade cancer) } \\
(\mathrm{n}=44)\end{array}$ \\
\hline $\begin{array}{c}\text { Low/negative ANGPTL4 expression } \\
\text { 15(75\%) }\end{array}$ & $6(60 \%)$ \\
High/moderate ANGPTL4 expression & $6(13.6 \%)$ \\
$5(25 \%)$ & $4(40 \%)$ & $38(86.4 \%)$ \\
\hline
\end{tabular}

ANGPTL4: angiopoietin like protein 4; $\mathrm{P}$ value was calculated by chisquare test; P was considered significant at $<0.001 ; *$ Significant

Table 1. Demographic and Laboratory Findings of the Studied Groups

\begin{tabular}{|c|c|c|c|c|c|}
\hline & \multirow{2}{*}{$\begin{array}{c}\text { Group I } \\
\text { (control) } \\
(n=20)\end{array}$} & \multirow{2}{*}{$\begin{array}{c}\text { Group IIa } \\
\text { (low grade cancer) } \\
(\mathrm{n}=10)\end{array}$} & \multirow{2}{*}{$\begin{array}{c}\text { Group IIb } \\
\text { (high grade cancer) } \\
(\mathrm{n}=44)\end{array}$} & \multicolumn{2}{|c|}{ ANOVA } \\
\hline & & & & $\mathrm{f}$ & P-value \\
\hline Age (years) & $49.1 \pm 5.3$ & $47.3 \pm 5.3$ & $49.9 \pm 5.3$ & 1.054 & 0.354 \\
\hline ANGPTL-4 mRNA relative expression & $0.70 \pm 0.02 * \#$ & $1.21 \pm 0.32 \#$ & $1.47 \pm 0.31$ & 55.862 & $<0.001 *$ \\
\hline Serum ANGPTL-4 (ng/ml) & $65.34 \pm 6.41 * \#$ & $171.76 \pm 7.58 \#$ & $184.98 \pm 18.18$ & 462.282 & $<0.001 *$ \\
\hline Serum HIF- $1 \alpha(\mu \mathrm{g} / \mathrm{L})$ & $33.95 \pm 3.11 * \#$ & $139.14 \pm 5.83 \#$ & $148.54 \pm 14.20$ & 722.669 & $<0.001 *$ \\
\hline NFKB/p65 binding activity & $0.13 \pm 0.03 * \#$ & $0.36 \pm 0.04 \#$ & $0.79 \pm 0.03$ & 461.288 & $<0.001^{*}$ \\
\hline Serum IL-1 $\beta(\mathrm{pg} / \mathrm{ml})$ & $7.83 \pm 0.92 * \#$ & $184.23 \pm 37.75 \#$ & $247.13 \pm 44.35$ & 287.345 & $<0.001 *$ \\
\hline
\end{tabular}

ANGPTL4: angiopoietin like protein 4; HIF-1a: hypoxia inducible factor-1 alpha ; NFKB/p65: nuclear factor kappa B/p65 subunit ; IL-13: interleukin-1beta . *Data are presented as the mean $\pm \mathrm{SD} ; *$ statistically significant at $p<0.05 ; *$ as compared to low grade breast carcinoma group; \#as compared to high grade breast carcinoma group

Table 3. Pearson's Correlations between the Studied Parameters

\begin{tabular}{|c|c|c|c|c|c|c|}
\hline & & $\begin{array}{c}\text { Age } \\
\text { (years) }\end{array}$ & $\begin{array}{c}\text { ANGPTL-4 } \\
\text { mRNA relative } \\
\text { expression }\end{array}$ & $\begin{array}{c}\text { Serum } \\
\text { ANGPTL-4 } \\
(\mathrm{ng} / \mathrm{ml})\end{array}$ & $\begin{array}{l}\text { Serum } \\
\text { HIF-1 } \alpha \\
(\mu \mathrm{g} / \mathrm{L})\end{array}$ & $\begin{array}{c}\text { NFKB/p65 } \\
\text { binding } \\
\text { activity }\end{array}$ \\
\hline ANGPTL-4 mRNA relative expression & $\begin{array}{c}r \\
\text { P-value }\end{array}$ & $\begin{array}{l}0.047 \\
0.738\end{array}$ & & & & \\
\hline Serum ANGPTL-4 (ng/ml) & $\begin{array}{c}\mathrm{r} \\
\text { P-value }\end{array}$ & $\begin{array}{l}0.103 \\
0.459\end{array}$ & $\begin{array}{l}0.297 \\
0.020 *\end{array}$ & & & \\
\hline Serum HIF- $1 \alpha(\mu \mathrm{g} / \mathrm{L})$ & $\begin{array}{c}r \\
\text { P-value }\end{array}$ & $\begin{array}{l}0.235 \\
0.087\end{array}$ & $\begin{array}{c}0.495 \\
<0.001 *\end{array}$ & $\begin{array}{c}0.495 \\
<0.001 *\end{array}$ & & \\
\hline NFKB/p65 binding activity & $\begin{array}{c}\mathrm{r} \\
\text { P-value }\end{array}$ & $\begin{array}{l}0.034 \\
0.807\end{array}$ & $\begin{array}{l}0.328 \\
0.015^{*}\end{array}$ & $\begin{array}{l}0.41 \\
0.002 *\end{array}$ & $\begin{array}{l}0.394 \\
0.005^{*}\end{array}$ & \\
\hline Serum IL-1 $\beta(\mathrm{pg} / \mathrm{ml})$ & $\begin{array}{c}r \\
\text { P-value }\end{array}$ & $\begin{array}{l}0.04 \\
0.772 \\
\end{array}$ & $\begin{array}{c}0.492 \\
<0.001 * \\
\end{array}$ & $\begin{array}{c}0.488 \\
<0.001 *\end{array}$ & $\begin{array}{c}0.657 \\
<0.001 *\end{array}$ & $\begin{array}{c}0.786 \\
<0.001 *\end{array}$ \\
\hline
\end{tabular}

ANGPTL4: angiopoietin like protein 4; HIF-1a: hypoxia inducible factor-1 alpha ; NFKB/p65: nuclear factor kappa B/p65 subunit ; IL-1 $\beta$ : interleukin1beta .P was considered significant at $<0.05$; *Significant 
Table 4. Association between ANGPTL4 Protein Expression and Clinico-pathological Features in Cancer Group

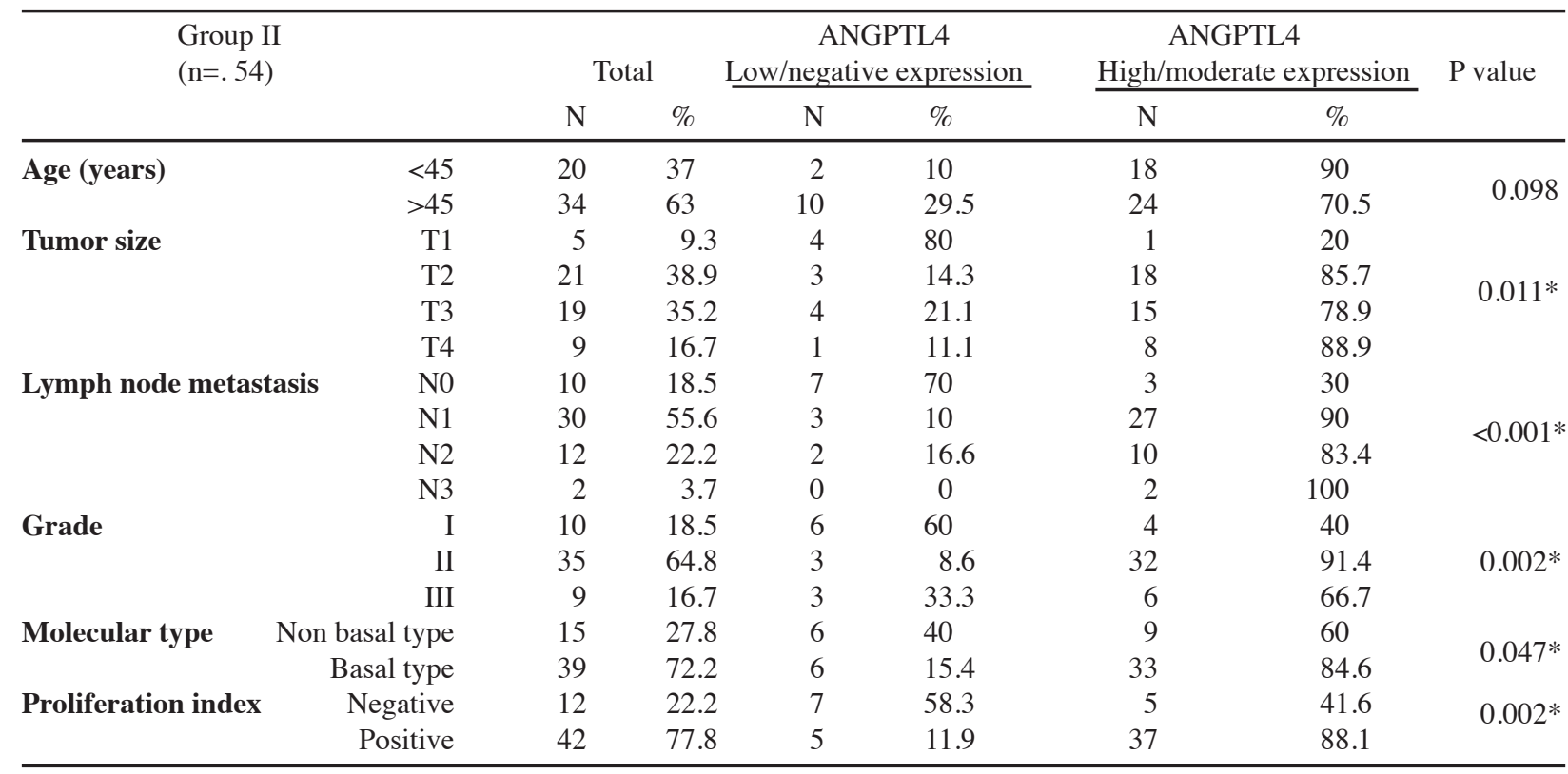

ANGPTL4: angiopoietin like-4; $\mathrm{P}$ value was calculated by chi-square test; $\mathrm{P}$ was considered significant at $<0.05$; $*$ Significant

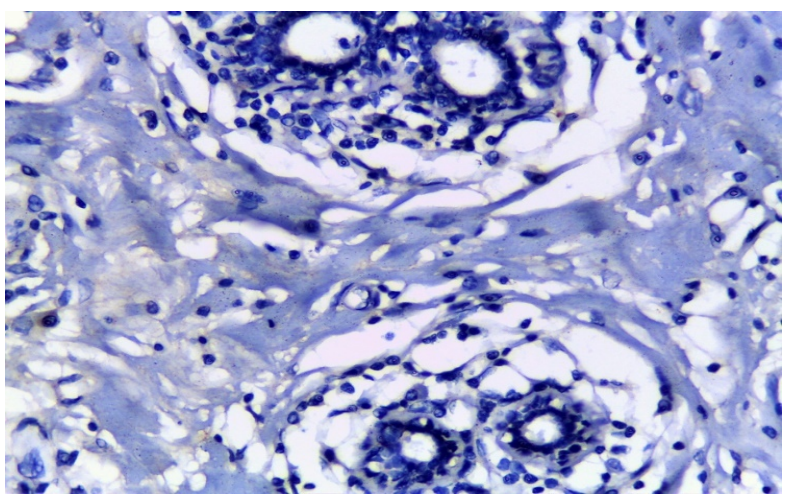

Figure 1.Immunohistochemical staining of ANGPTL4 in control case showed negative ANGPTL4 immunohistochemical expression in normal breast tissue (X400)

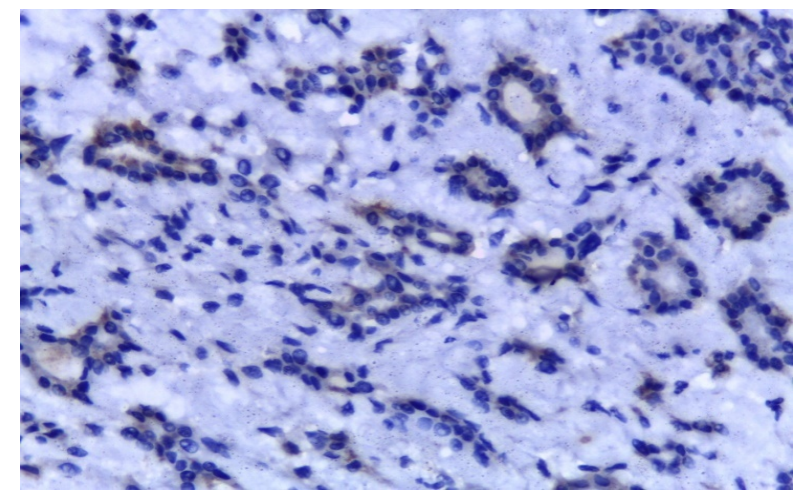

Figure 2. Immunohistochemical Staining of ANGPTL4 in case of Invasive Breast Carcinoma Grade I Showed Low ANGPTL4 Immunohistochemical Expression (X200)

carcinoma were examined in table (3), no significant correlations were found between age and other studied parameters. Serum levels of ANGPTL4 exhibited a significant positive correlation with HIF- $1 \alpha, \mathrm{NF}-x \beta / \mathrm{p} 65$ DNA binding activity and IL-1 $\beta(r=0.495, r=41$ and $r$

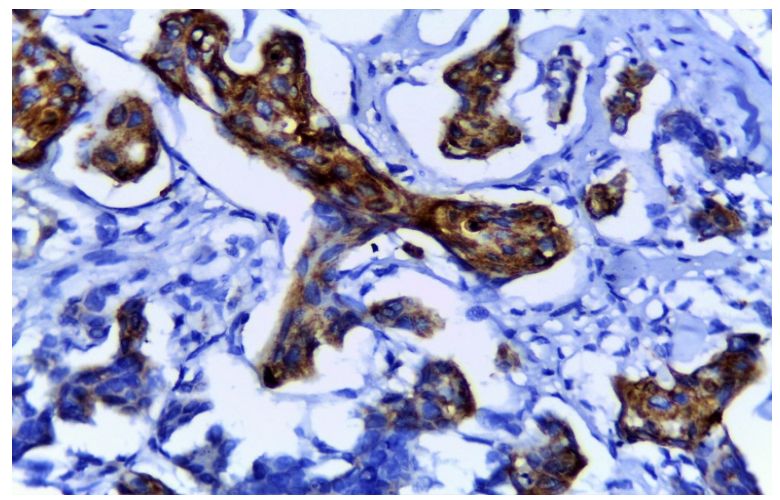

Figure 3. Immunohistochemical Staining of ANGPTL4 in Case of Invasive Breast Carcinoma Grade II Showed High ANGPTL4 Immunohistochemical Expression (X400)

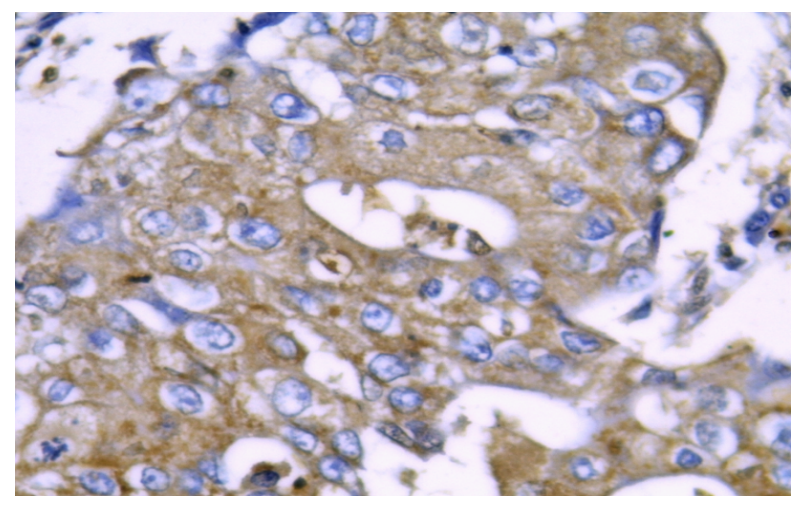

Figure 4. Immunohistochemical staining of ANGPTL4 in case of invasive breast carcinoma grade III showed moderate ANGPTL4 immunohistochemicalexpression (X400)

$=0.488$, respectively $)(p<.05)$ and with relative mRNA expression $(r=0.297)(p<.05)$. In addition, serum levels of HIF- $1 \alpha$ showed positive correlations with NF- $x \beta / \mathrm{p} 65$ DNA binding activity and IL-1 $\beta$, as well as relative mRNA expression ( $r=0.394, r=0.657$ and $r=0.495$, respectively) 
$(p<.05) . \mathrm{NF}-x \beta /$ p65 DNA binding activity exhibited positive correlations with IL- $1 \beta$ and with ANGPTL4 relative mRNA expression $(r=0.786$ and $r=0.328)(p$ $<.05)$. Finally, IL-1 $\beta$ showed positive correlations with ANGPTL4 relative mRNA expression $(r=0.492)$. Table (4) represents histopthological and immunohistochemical findings. As can be seen from the data, an elevated ANGPTL4 protein expression in breast carcinoma cases was significantly associated with lymph node metastasis, grade, tumor size and proliferation markers. However, there was no correlation between ANGPTL4 protein expression and patient's age. As 54 cases were diagnosed as invasive ductal carcinoma (Group II), 10/54 (18.5\%) cases were classified as Grade I, 35/54 (64.8\%) cases were diagnosed as Grade II, and 9/54 (16.7\%) cases were of Grade III. Thus, patients in Group I were considered as having low-grade cancer, whereas those in Group II and III were considered as having high-grade cancer. With respect to the tumor size, 5/54 $(9.3 \%)$ cases were classified as T1, 21/54 (38.9\%) cases were T2, 19/54 (35.2\%) cases were T3, and 9/54 (16.7\%) cases were classified as T4. Moreover, 10/54 (18.5\%) cases showed no lymph node metastasis, while 30/54 (55.6\%) cases were N1, 12/54 $(22.2 \%)$ cases were N2 and $2 / 54(3.7 \%)$ cases were N3. According to ER, PR, HER-2/new, CK5/6 and EGFR expression and the breast cancer cases could be further classified based on the molecular subtypes. According to this grouping, 39/54 (72.2\%) cases were basal subtypes (as they showed ER-, PR-, HER2-, CK5/6+ and or EGFR+) and $15 / 54(27.8 \%)$ cases were of non-basal subtype, which were further divided into luminal $\mathrm{A}(\mathrm{ER}+, \mathrm{PR}+/-, \mathrm{HER} 2-)$ or luminal B (ER+, PR+/-, HER2+). Finally, with respect to KI-67 proliferation index, 12/54 (22.2\%) cases were KI-67 negative and 42/54(77.8\%) were KI-67 positive. These results are confirmed in Figures 1, 2 and 3.

\section{Discussion}

The novel adipocytokine, angiopoietin-like protein 4, is posited to play an important role in cancer progression and pathogenesis (Tan et al., 2012). Various types of human cancers were found to have altered expression of ANGPTL4 (Li et al., 2011; Kim et al., 2011). However, its role in breast carcinoma as well as its relevance to inflammation-related cancer progression remains controversial. The present study revealed that ANGPTL4 serum levels as well as its protein and mRNA expressions were significantly higher in cancerous breast tissue compared to normal breast tissue samples. In addition, increased tumor size, lymph node metastasis, high-grade breast carcinoma and proliferation index were associated with higher ANGPTL4 tissue expression, suggesting that ANGPTL4 plays a role in tumor progression and cancer cell differentiation. In line with these findings, increased mRNA and protein expressions of ANGPTL4 have been previously reported in other cancer types, such as oral Kaposi sarcoma and ovarian carcinoma (Hu et al., 2011; Brunckhorst et al., 2014). This phenomenon can be explained by the fact that tumor-derived ANGPTL4 facilitated disruption of vascular endothelial cell-cell junctions and tumor cell extravasation into other tissues, which ultimately leads to micro metastases (Padua et al., 2008). The same finding was reported by Zhang et al., 2012 who concluded that breast cancer metastasis was promoted by ANGPTL4. Similarly, Yi et al., 2013 reported that, in esophageal squamous cell carcinoma, higher expression levels of ANGPTL4 were correlated with more advanced tumor stages and more adverse clinical outcomes. In the present study, significantly higher protein expressions of ANGPTL4 in basal type of invasive duct carcinoma were noted relative to the non-basal type. This finding is in agreement with the results reported by Yotsumoto et al., 2013 who found that ANGPTL4 expression was involved in aggressive tumor metastasis to lungs and brain and in tumor development in triple negative breast cancer xenograft model. In the current study, there were significant differences between ANGPTL4 and proliferation index of breast cancer, thus concurring with Brunckhorst et al., 2014 who reported that ANGPTL4 significantly increased the number of proliferating ovarian cancer cells and KI-67. ANGPTL4induced breast carcinoma proliferation may be achieved through tumor-derived ANGPTL4 interaction with integrins, which stimulate the prosurvival pathways, phosphoinositide 3-kinases/ protein kinase B (PI3K/ $\mathrm{PKB} \alpha$ ) and extracellular signal-regulated kinase (ERK) through NADPH oxidase-dependent production of O2and proto-oncogene tyrosine-protein kinase Src, thus, promoting anoikis and tumor growth (Zhu et al., 2011). Further supporting the tumor induction role of ANGPTL4, Tan et al., 2012 reported that ANGPTL4 functions as a negative regulator of apoptosis. It is particularly noteworthy that, under tumor hypoxic conditions, ANGPTL4 is regulated by HIF-1 $\alpha$ (Wagner et al., 2011). In addition, in microarray analysis, ANGPTL4 was found to be the only gene bound and highly induced by the two different regulators, peroxisome proliferators-activated receptor family $(\mathrm{PPAR} \beta / \delta$ ) and HIF- $1 \alpha$ (Inoue et al., 2014). Contrary to the results of the current study, $\mathrm{Ng}$ et al., 2014 and Galaup et al., 2006 reported that ANGPTL4 suppressed growth, angiogenesis and metastasis in hepatocellular carcinoma and melanoma. Tumor progression and treatment response are highly affected by hypoxia ( $\mathrm{Li}$ et al., 2015). The current study revealed a significant increase in serum HIF-1 $\alpha$ levels in high grade breast cancer patients compared to low grade cancer and control subjects. This finding can be explained by the fact that protein translation and proteasome-dependent degradation are impaired by hypoxia, which affects the HIF-1 $\alpha$ levels (Anad et al., 2011). Furthermore, these results are in line with the previous findings indicating that mature and functional HIF-1 $\alpha$ are generated by cells in response to hypoxia in solid tumors (Kafshdooz et al., 2014) which plays a pivotal role in tumor progression, infiltration and metastasis (Unwith et al., 2015). The results yielded by this study also demonstrated that serum HIF-1 $\alpha$ was significantly correlated with ANGPTL4 serum and expression levels. This finding is in keeping with the notion of an existing crosstalk or interplay between ANGPTL4 and HIF-1 $\alpha$, particularly in cancer progression. In agreement, Potente et al., 2011 reported that tumor angiogenesis is orchestrated by angiogenic 
factors, including angiopoietin-like proteins and enhanced by HIF-1 $\alpha$. In addition, Inoue et al., 2014 found five HIF$1 \alpha$ binding sites, identified under hypoxia in the ANGPTL4 gene locus, suggesting that hypoxia is an activator of ANGPTL4 gene. The authors further asserted that pro-inflammatory cytokines in tumor microenvironment and the subsequent activation of NF-kB transcription factor play a role in tumor pathogenesis and progression. In this context, we further investigated the serum levels of IL-1 $\beta$ and DNA-binding capacity of NF-kB/p65 in breast cancer. The present study showed that the DNA binding capacity of the p 65 subunit of NF- $\varkappa$ B significantly increased in PMNCs from high-grade breast cancer patients compared to those with low-grade cancer and the control subjects. This finding is consistent with the results reported by Wang et al., 2013 who noted that, in human breast cancer cell line, NF- $\varkappa \mathrm{B}$ transcriptional activity was increased secondary to overexpression of $\mathrm{NF}-\varkappa \mathrm{B} / \mathrm{p} 65$. Consequently, cancer progression and metastasis can be promoted by active NF- $x \mathrm{~B}$ signaling through induction of several cell cycle, anti-apoptotic and chemotactic regulatory genes that enhance tumor (Xia et al., 2014). It can thus be postulated that an existing interplay between $\mathrm{NF}-\varkappa \mathrm{B}$ and HIF- $1 \alpha$ particularly in carcinogenesis has been established. The present study revealed that serum HIF-1 $\alpha$ was significantly correlated with NF- $\varkappa$ B/P65 activity and that both played an important role in tumor progression. HIF-1 $\alpha$ protein accumulation under hypoxia requires the participation of $\mathrm{NF}-\varkappa \mathrm{B}$, which is a critical transcriptional activator of HIF- $1 \alpha$ (Taylor and Cummins, 2009). Moreover, authors of several studies focusing on different cancer types reported that hypoxia-inducible factor- $1 \alpha$ is up-regulated by a hypoxia-dependent transcription by NF- $\varkappa$ B (Yoshida et al., 2013), stimulating epithelial to mesenchymal transition (Cheng et al., 2014), thus promoting tumor progression and angiogenesis. NF-kB transcription factor plays a crucial role in tumor development through transcriptional regulation of genes associated with tumor growth, invasion and metastasis, including cytokines such as IL-1 $\beta$ (Tewari et al., 2012). The present study revealed that IL- $1 \beta$ serum levels were significantly increased in patients with high-grade breast cancer compared to those with low-grade cancer and to the control subjects. At the cellular level, IL-1 $\beta$ exerts its effects through binding of IL-1 receptor I (IL-1RI) and recruitment of the co-receptor, interleukin-1 receptor accessory protein, thus inducing cellular changes and signal transduction (Aggarwal et al., 2006). In cancer cells, several authors observed that IL- $1 \beta$ acts via autocrine and/ or paracrine mechanisms, positing that it may regulate the expression of angiogenic factors, such as IL-8, thus promoting angiogenesis and tumor progression (Katanov et al., 2015). In addition, IL- $1 \beta$ contributes to the progression of tumors through stimulation of cell growth and differentiation and the inhibition of apoptosis of altered cells at the inflammatory site (Snoussi et al., 2005). The results yielded by the present study are in good agreement with those reported by Saijo et al. 2002, who demonstrated that interleukin IL- $1 \beta$ autocrine production in pancreatic carcinoma cell lines induced tumor growth and confers chemoresistance. With respect to the positive correlation between IL- $1 \beta$ and HIF- $1 \alpha$, IL-1 $\beta$ and TNF- $\alpha$ have been shown to increase HIF-1 $\alpha$ activity in breast cancer through activation of NF- $x \beta$ pathway (Tewari et al., 2012). In addition, IL-1 $\beta$ mediated up-regulation of HIF-1 $\alpha$ via an NF-kB/Cyclooxygenase- 2 pathway was reported to identify HIF-1 as a critical link between inflammation and oncogenesis progression (Jung et al., 2003). Nevertheless, in this study, strong positive correlations between ANGPTL4 levels and HIF- $1 \alpha$, NF$\chi \mathrm{B} / \mathrm{p} 65$ activity and IL- $1 \beta$ in breast cancer patients were noted, reflecting ANGPTL4 involvement in inflammatory pathways associated with breast cancer progression. Collectively, serum levels of ANGPTL4, HIF- $1 \alpha$, and IL- $1 \beta$ and $\mathrm{NF}-x \mathrm{~B} / \mathrm{p} 65$ activity were significantly associated with breast carcinoma pathogenesis and progression.

In conclusion, ANGPTL4 high serum levels and tissue expressions in advanced grade breast cancer, in addition to its positive correlation with tumor clinico-pathological features and HIF-1 $\alpha$ could highlight its role as one of the signaling factors involved in breast cancer progression. Moreover, novel correlations were found between ANGPTL4 and the inflammatory markers, IL-1 $\beta$ and $\mathrm{NF}-\varkappa \mathrm{B} / \mathrm{p} 65$, in breast cancer, which may emphasize the utility of these markers as potential tools for understanding interactions for axes of carcinogenesis and inflammation contributed for cancer progression. It is thus hoped that the findings reported here would assist in the development of new breast cancer management strategies that would promote patients' quality of life and ultimately improve clinical outcomes. However, large-scale studies are needed to verify these results.

\section{Disclosures}

Funding: No grants or funding have been received for this study.

Conflict of interest: the authors declare that they have no conflict of interests.

\section{References}

Aggarwal BB, Shishodia S, Sandur SK, et al (2006). Inflammation and cancer: how hot is the link? Biochem Pharmacol, 72, 1605-21.

Anand K, Asthana P, Kumar A, et al (2011). Quercetin mediated reduction of angiogenic markers and chaperones in DLAinduced solid tumours. Asian Pac J Cancer Prev, 12, 2829-35.

Biswas DK, Martin KJ, McAlister C, et al (2003). Apoptosis caused by chemotherapeutic inhibition of nuclear factorkappaB activation. Cancer Res, 63, 290-5.

Bradford MM (1976). A rapid and sensitive method for the quantitation of microgram quantities of protein utilizing the principle of protein-dye binding. Anal Biochem, 72, 248-54.

Brunckhorst MK, Xu Y, Lu R, et al (2014). Angiopoietins promote ovarian cancer progression by establishing a procancer microenvironment. Am J Pathol, 184, 2285-96.

Cheng ZX, Wang DW, Liu T, et al (2014). Effects of the HIF-1 $\alpha$ and NF- $x \mathrm{~B}$ loop on epithelial-mesenchymal transition and chemoresistance induced by hypoxia in pancreatic cancer cells. Oncol Rep, 31, 1891-8.

Feingold KR, Shigenaga JK, Cross AS, et al (2012). Angiopoietin like protein 4 expression is decreased in activated 
macrophages. Biochem Biophys Res Commun, 421, 612-5.

Gaballah HH, Zakaria SS, Ismail SA (2014). Activity and expression pattern of NF- $\varkappa \mathrm{B} / \mathrm{P} 65$ in peripheral blood from hepatocellular carcinoma patients - link to hypoxia inducible factor -1 $\alpha$. Asian Pac J Cancer Prev, 15, 6911-7.

Galaup A, Cazes A, Le Jan S, et al (2006). Angiopoietinlike 4 preventsmetastasis through inhibition of vascularpermeability and tumorcellmotility and invasiveness. Proc Natl Acad Sci U S A, 103, 18721-6.

Gong JP, Liu CA, Wu CX, et al (2002). Nuclear factor kB activity in patients with acute severe cholangitis. World $J$ Gastroenterol, 8, 346-9.

González-Ramos R, Rocco J, Rojas C, et al (2012). Physiologic activation of nuclear factor kappa-B in the endometrium during the menstrual cycle is altered in endometriosis patients. Fertil Steril, 97, 645-51.

Görlach A, Bonello S (2008). The cross-talk between NF-kappaB and HIF-1: further evidence for a significant liaison. Biochem $J, 412,17-9$.

Holliday DL, Speirs V (2011). Choosing the right cell line for breast cancer research. Breast Cancer Res, 13, 215.

Hu J, Jham BC, Ma T, et al (2011). Angiopoietin-like 4: a novel molecular hallmark in oral Kaposi's sarcoma. Oral Oncol, 47, 371-5.

Inoue T, Kohro T, Tanaka T, et al (2014). Cross-enhancement of ANGPTL4 transcription by HIF1 alpha and PPAR beta/ delta is the result of the conformational proximity of two response elements. Genome Biol, 15, 63 .

Jung YJ, Isaacs JS, Lee S, et al (2003). IL-1beta-mediated upregulation of HIF-1alpha via an NFkappaB/COX-2 pathway identifies HIF-1 as a critical link between inflammation and oncogenesis. FASEB J, 17, 2115-7.

Kafshdooz L, Tabrizi AD, Mohaddes SM, (2014). The polymorphism of hypoxia-inducible factor-1a gene in endometrial cancer. Asian Pac J Cancer Prev, 15, 10393-6.

Katanov C, Lerrer S, Liubomirski Y, et al (2015). Regulation of the inflammatory profile of stromal cells in human breast cancer: prominent roles for TNF- $\alpha$ and the NF- $x$ B pathway. Stem Cell Res Ther, $6,87$.

Khong TL, Thairu N, Larsen H, et al (2013). Identification of the angiogenic gene signature induced by EGF and hypoxia in colorectal cancer. BMC Cancer, 13, 518 .

Kim SH, Park YY, Kim SW, et al (2011). ANGPTL4induction by prostaglandin E2 under hypoxic conditions promotes colorectal cancer progression. Cancer Res, 71, 7010-20.

Li H, Ge C, Zhao F, et al (2011). HIF-1-activated ANGPTL4 contributes to tumor metastasis via VCAM-1/integrin b1 signaling in human hepatocellular carcinoma. Hepatology, $\mathbf{5 4}, 910-9$.

Li Y, Miao LY, Xiao YL, et al (2015). Hypoxia induced high expression of thioredoxin interacting protein (TXNIP) in Non-small cell lung cancer and its prognostic effect. Asian Pac J Cancer Prev, 16, 2953-8.

$\mathrm{Ng} \mathrm{KT}, \mathrm{Xu} \mathrm{A}$, Cheng Q, et al (2014). Clinical relevance and therapeutic potential of angiopoietin-like protein 4 in hepatocellular carcinoma. Mol Cancer, 13, 196.

Padua D, Zhang XH, Wang Q, et al (2008). TGF beta primes breast tumors for lung metastasis seeding through angiopoietin-like 4. Cell, 133, 66-77.

Pandey S, Singh S, Anang V, et al (2015). Pattern Recognition Receptors in Cancer Progression and Metastasis. Cancer Growth Metastasis, 8, 25-34.

Potente M, Gerhardt H, Carmeliet P(2011). Basic and therapeutic aspects of angiogenesis. Cell, 146, 873-87.

Philip M, Rowley DA, Schreiber H (2004). Inflammation as a tumor promoter in cancer induction. Semin Cancer Biol, 14, 433-9.
Rider P, Carmi Y, Guttman O, et al (2011). IL- $1 \alpha$ and IL-1 $\beta$ recruit different myeloid cells and promote different stages of sterile inflammation. J Immunol, 187, 4835-43.

Saijo Y, Tanaka M, Miki M, et al (2002). Proinflammatory cytokine IL-1 beta promotes tumor growth of Lewis lung carcinoma by induction of angiogenic factors: in vivo analysis of tumor-stromal interaction. J Immunol, 169, 469-75.

Santulli G (2014). Angiopoietin-like proteins: a comprehensive look. Front Endocrinol (Lausanne), 5, 4.

Snoussi K, Strosberg AD, Bouaouina N, et al (2005). Genetic variation in pro-inflammatory cytokines (interleukin-1beta, interleukin-1alpha and interleukin-6) associated with the aggressive forms, survival, and relapse prediction of breast carcinoma. Eur Cytokine Netw, 16, 253-60.

Taghavi A, Fazeli Z, Vahedi M, et al (2012). Increased trend of breast cancer mortality in Iran. Asian Pac J Cancer Prev, 13, 367-70.

Tan MJ, Teo Z, Sng MK, et al (2012). Emerging roles of angiopoietin-like 4 in human cancer. Mol Cancer Res, 10, 677-88.

Taylor CT, Cummins EP (2009). The role of NF-kappaB in hypoxia-induced gene expression. Ann N Y Acad Sci, 1177, 178-84.

Tewari R, Choudhury SR, Ghosh S, et al (2012). Involvement of TNF $\alpha$-induced TLR4-NF- $x$ B and TLR4-HIF- $1 \alpha$ feedforward loops in the regulation of inflammatory responses in glioma. J Mol Med (Berl), 90, 67-80.

Unwith S, Zhao H, Hennah L, et al (2015). The potential role of $\mathrm{HIF}$ on tumour progression and dissemination. Int J Cancer, 136, 2491-503.

Van Laere SJ, Van der Auwera I, Van den Eynden GG, et al (2006). Nuclear factor-kappaB signature of inflammatory breast cancer by cDNA microarray validated by quantitative real-time reverse transcription PCR, immuno-histochemistry, and nuclear factor-kappaB DNA-binding. Clin Cancer Res, 12, 3249-56.

van Loo G, Beyaert R (2011). Negative regulation of NF- $x$ B and its involvement in rheumatoid arthritis. Arthritis Res Ther, 31, 221.

Wagner KD, Benchetrit M, Bianchini L, et al (2011). Peroxisome proliferator-activated receptor beta/delta (PPARbeta/delta) is highly expressed in liposarcoma and promotes migration and proliferation. J Pathol, 224, 575-588.

Wang F, Ma J, Wang KS, et al (2015). Blockade of TNF- $\alpha$-induced $\mathrm{NF}-x \mathrm{~B}$ signaling pathway and anti-cancer therapeutic response of dihydrotanshinone I. Int Immunopharmacol, 28, 764-72.

Wang L, Kang F, Li J, et al (2013). Overexpression of p65 attenuates celecoxib-induced cell death in MDA-MB-231 human breast cancer cell line. Cancer Cell Int, 13, 14.

Xia JT, Chen LZ, Jian WH, (2014). MicroRNA-362 induces cell proliferation and apoptosis resistance in gastric cancer by activation of NF- $x \mathrm{~B}$ signaling. $J$ Transl Med, 12, 33.

Xia T, Cheng H, Zhu Y (2014). Knockdown of hypoxia-inducible factor-1 alpha reduces proliferation, induces apoptosis and attenuates the aggressive phenotype of retinoblastoma WERI-Rb-1 cells under hypoxic conditions. Ann Clin Lab Sci, 44, 134-44.

Yi J, Pan BZ, Xiong L, Song HZ (2013). Clinical significance of angiopoietin-likeprotein4expression in tissue and serum of esophageal squamous cell carcinoma patients. Med Oncol, 30, 680 .

Yoshida T, Hashimura M, Mastumoto T, et al (2013). Transcriptional upregulation of HIF- $1 \alpha$ by NF- $\varkappa \mathrm{B} / \mathrm{p} 65$ and its associations with $\beta$-catenin/p300 complexes in endometrial carcinoma cells. Lab Invest, 93, 1184-93. 
Yotsumoto F, Tokunaga E, Oki E, et al (2013). Molecular hierarchy of heparin-binding EGF-like growth factorregulated angiogenesis in triple-negative breast cancer. $\mathrm{Mol}$ Cancer Res, 11, 506-17.

Zhang H, Wong CC, Wei H, et al (2012). HIF-1-dependent expression of angiopoietin-like 4 and L1CAM mediates vascular metastasis of hypoxic breast cancer cells to the lungs. Oncogene, 31,1757-70.

Zhang ZG, Zhang QN, Wang XH, et al (2013). Hypoxiainducible factor 1 alpha (HIF-1 $\alpha$ ) as a prognostic indicator in patients with gastric tumors: a meta-analysis. Asian Pac J Cancer Prev, 14, 4195-8.

Zhu P, Tan MJ, Huang RL, et al (2011). Angiopoietin-like 4 protein elevates the prosurvival intracellular $\left.\mathrm{O}_{2}-\right): \mathrm{H}_{2} \mathrm{O}_{2}$ ratio and confers anoikis resistance to tumors. Cancer Cell, 19, 401-15. 